\title{
LOCAL EQUIVALENT WATER THICKNESS DETERMINATION AS A SOURCE OF DATA FOR FLOOD PHENOMENON OBSERVATION
}

\author{
MONIKA BIRYŁO ${ }^{1}$, JOLANTA NASTULA ${ }^{2}$, \\ ${ }^{1}$ University of Warmia and Mazury, Department of Astronomy and Geodynamics \\ Heweliusza St. 10/2, 10-724 Olsztyn, Poland \\ monika.sienkiewicz@uwm.edu.pl \\ 2 Space Research Center Polish Academy of Science \\ Bartycka St. 18A, 00-716 Warsaw, Poland \\ nastula@cbk.waw.pl
}

\begin{abstract}
In the paper a flood phenomenon is analyzed. For this purpose data from GRACE satellites (Gravity Recovery and Climate Experiment) was used. Filtered data presented in a form of millimeters of Equivalent Water Thickness (EWT) was interpolated in places where flood in 2010 had happened (south of Poland). On a basis of graph where time series of EWT were presented, some conclusions were made. For the thesis confirmation meteorological WGHM and hydrological NOAA models were added to the GRACE model.
\end{abstract}

KEY WORDS: GRACE, Equivalent Water Thickness, flood.

\section{INTRODUCTION}

Directive 2007/60/EC of the European Parliament and of the Council on the assessment and management of flood risk makes it compulsory to monitor flood risk. Poland has a large floods especially in the spring, and the smallest in the autumn and winter months. Ratio of the maximum to the minimum flow rate is 2.6 (Kleski... 
1993, Dynowska 1993). Variability of rainfall and flow and groundwater level makes number of periods of water scarcity (a detrimental effect on plant growth) or periods of flooding. Both of them will cause social and economic losses (Powódź... 1998). Many years of observation have shown that the biggest threat to Poland cause prolonged heavy rains in parts of the upper Vistula and Oder, and depressed areas of Żuławy (Mioduszewski and Pasternak 1995).

Created models based on GRACE (Gravity Recovery and Climate Experiment) data can be useful in the implementation of tasks resulting from the Directive.

\section{GRACE MISSION AND ITS IMPORTANCE}

Satellites of the mission called Gravity Recovery and Climate Experiment (GRACE) were launched and placed in orbit in 2002, and provide information about the variation in time of the gravity field of the Earth. Satellites are on a low, $500-\mathrm{km}$ orbit at a distance from each other about 200 kilometers - between 170 and $270 \mathrm{~km}$ (Beerer and Massmann 2007, Tapley et al. 2004). Disorders of the gravitational field of the Earth causes a slight change in the distance between the two GRACE satellites. These changes are calculated by the high-precision systems operating in the microwave band K (KBR - K-Band Ranging). KBR time synchronization unit provides a GPS system. In addition, the transmitter operating in S-band allows to communicate with stationary tracking stations. Use of the technique low low Satellite-to-Satellite Tracking - 11-SST allows for precision measurement of changes in the distance between the ships of a few microns (Drożyner 2005). GPS satellites help to determine the precise position of the two GRACE satellites in orbit. In addition, satellite position is determined from observations of ground-based laser station. Since the distance between the satellites and their speed is known with high accuracy, it is possible to precisely determine the relative change in the distance between the satellites. On-board accelerometers are used to measure the non-gravitational acceleration (Tapley et al. 2004).

Monthly observations from the GRACE satellites contain signals which are result of mass changes over continents, oceans, in the interior of the Earth, atmosphere errors, ocean models and GRACE measurement errors. Data obtained from GRACE observations in different centers vary in the procedures and models of physical phenomena used to develop gravity data (Veselinova-Renglova 2007).

Since 2010, the product generated by Data Centers is to solve the RL-04 (Release Note 04). Solutions of the various centers are different, inter alia, the degree of a spherical harmonics expansion - from a degree of 60 or more. GRACE data are published as GSM files. They contain $\Delta C_{l, m}(t)$ and $\Delta S_{l, m}(t)$ coefficients of gravity field expansion into spherical harmonics series (Liu 2008). From the previous products, RL-04 varies widely (used tidal and static field models are more accurate) - Watkins et al. 2007. 
GRACE data processing is divided into three steps: pre-processing, processing and post-processing. Each of the three stages is independently developed by the centers, thus resulting differences in monthly spherical harmonics coefficients. GRACE data is collected by the following calculating centers:

- USA CSR (Center for Space Research);

- USA JPL (Jet Propulsion Laboratory);

- German GFZ (GeoForschungsZentrum);

- French CNES (Centre National d'Etudes Spatiales);

- Dutch TU Delft (Technische Universiteit Delft).

The easiest way to remove errors of a higher degree of spherical harmonics is to apply a simple filter of limiting spherical harmonics expansion. This approach has the disadvantage that it greatly reduces the signal strength, despite the removal of the systematic errors (Templey and Reiger 2008). Two ways of filtering GRACE data are used: isotropic and non-isotropic filter. Authors prepared an analysis of algorithms used for filtering data, but such analysis is not a purpose of the paper. To confirm the thesis, Annisotropic Non-Symmertic Filter (ANS) was used, described in equation (1) (Zhang 2009).

$$
f_{w}(x)=\frac{1}{4 \Pi R^{2}} \sum_{n=0}^{N}(f(y) W(x, y))
$$

where: $f_{w}$ - mass change, $R$ - Earth radius and a fiter $W(w, y)$ describes formula (2):

$$
W(x, y)=\sum_{l, m} \sum_{p, q} W_{l m, p q} Y_{l, m}^{\prime}(\xi) Y_{p, q}^{\prime}(\eta)
$$

where: $l, m$ are degree and order of a spherical harmonic expansion, $Y^{\prime}{ }_{l, m}-$ normalized spherical harmonic, $W_{l m, p q}$ - filtering coefficient, and $\xi$ and $\eta$ - coordinates of a point on a sphere.

ANS filter in non-symmetric in accordance to points $x, y$ and is dependent on both, degree and order. Moreover, it can minimize root-mean square error (Klees et al. 2008).

\section{GRACE DATA ANALYSIS}

For the purpose of analysis GRACE data for a period 2002.1-2010.12 was used. Series of spherical harmonic coefficient of degree and order 180 were converted to millimeters of Equivalent Water Thickness, which is a way of representing gravity variations. Equivalent Water Thickness can be described with formula below (Chambers 2006):

$$
\delta N(\varphi, \lambda, r)=R \sum_{l=2}^{\infty} \sum_{m=0}^{l}\left(\bar{C}_{l, m} \cos m \lambda+\bar{S}_{l, m} \sin m \lambda\right) \bar{P}_{l, m}^{n}(\sin \varphi) W_{n} \frac{(2 l+1)}{\left(1+k_{n}\right)}
$$


where: $\varphi$ is geographical latitude, $\lambda$ - geographical longitude, $\bar{P}_{l, m}^{n}(\sin \varphi)$ - normalized Legendre polynomial of $n$ degree and $m$ order, $k_{n}$ - load Love number of $n$ degree. $W_{n}$ is a filter. In a case of research, a chosen filter was that presented in equation (1).

Time interval of GRACE solution is roughly one month. Whole area of Poland was covered with a mesh grid with a step 0.5 degree. On a basis of a mesh grid, a value of EWT in four locations flood inundated in 2010 were interpolated with linear interpolation method (Nearest Neighbor method). The four places were: Wilków, Wrocław, Włocławek, Kraków. Since GRACE observation cannot be analyzed in a single point, as Earth is scanned by GRACE satellites in a wider expand, nearer points of mesh grid were added to the four localizations.

Results in a form of time series, are presented in Figure 1.

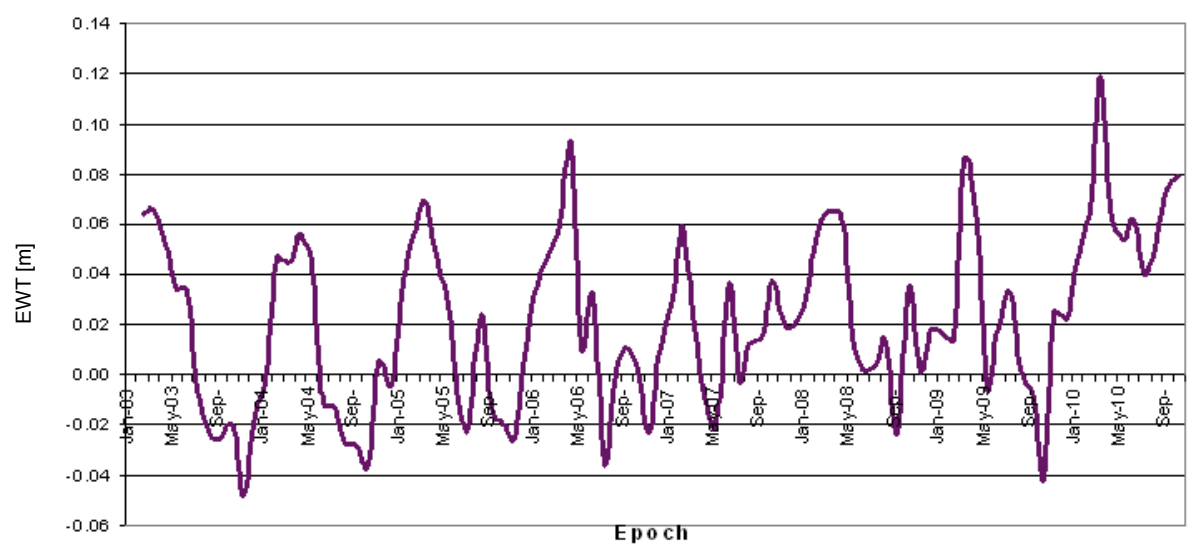

Figure 1. Average Equivalent Water Thickness for analyzed localizations

As can be seen from the Figure 1, the biggest EWT changes occur in the southern Poland in the month of March, and the lowest at the beginning of autumn. In addition, the graph shows a significant increase in the value of an Equivalent Water Thickness in March 2010, and two, three times more than the average of EWT (0.06) in the months of flood 2010, i.e. in May and June 2010. In March, the average Equivalent Water Thickness in the southern Poland is about $0.06 \mathrm{~mm}$, while in 2010, there were twice more $-0.12 \mathrm{~mm}$. In the coming months, usually the water level fell to $0.02 \mathrm{~mm}$, and in 2010, this state was $0.05 \mathrm{~mm}$. As it can see from the Figure 1, GRACE satellite data can be useful to assess the flood risk in Poland.

Slightly smaller increase in the value of the EWT were found in 2005 and 2009. In these years, after periods of large increases in the EWT, droughts occurred (level Equivalent Water Thickness after the wet fall to about $0.02 \mathrm{~mm}$, and in 2010 over the same period was about $0.08 \mathrm{~mm}$ ). In addition, in 2005 the value interpolated in 
four locations were very close, there was not a significant change of water mass in the southern Poland.

\section{CONFIRMATION - COMPARISON WITH NOAA AND WGHM MODELS}

An additional element that can help to control the accuracy of the analyzes was to compare the obtained EWT data from GRACE models with the values of the land hydrosphere. Two models were tested:

NOAA LadWorld Monthly Water Storage - National Oceanic and Atmopheric

Administration,

WGHM - WaterGAP (Global Assesment and Prognosis) Global Hydrology

Model.

NOAA meteorological satellites are low-orbital and gives Earth images in fivedegree spectrum (www.noaa.gov). NOAA terrestrial hydrosphere model called LadWorld Monthly Water Storage is published for the period: $1980.1 \div 2006.11$ in monthly one-degree grid (at the paper was used for the period: $2003.1 \div 2006.11$ ). NOAA model includes snow cover, water in the soil, ground water (shallow coverage), soil temperature, evaporation, water flow, reflectance parameters (Nastula et al. 2011). Data obtained from Global Geophysical Fluid Center (http://geophy.uni.lu/ggfc-hydrology.html) is shown in a Figure 2 with data from GRACE measurements (Fig. 1).

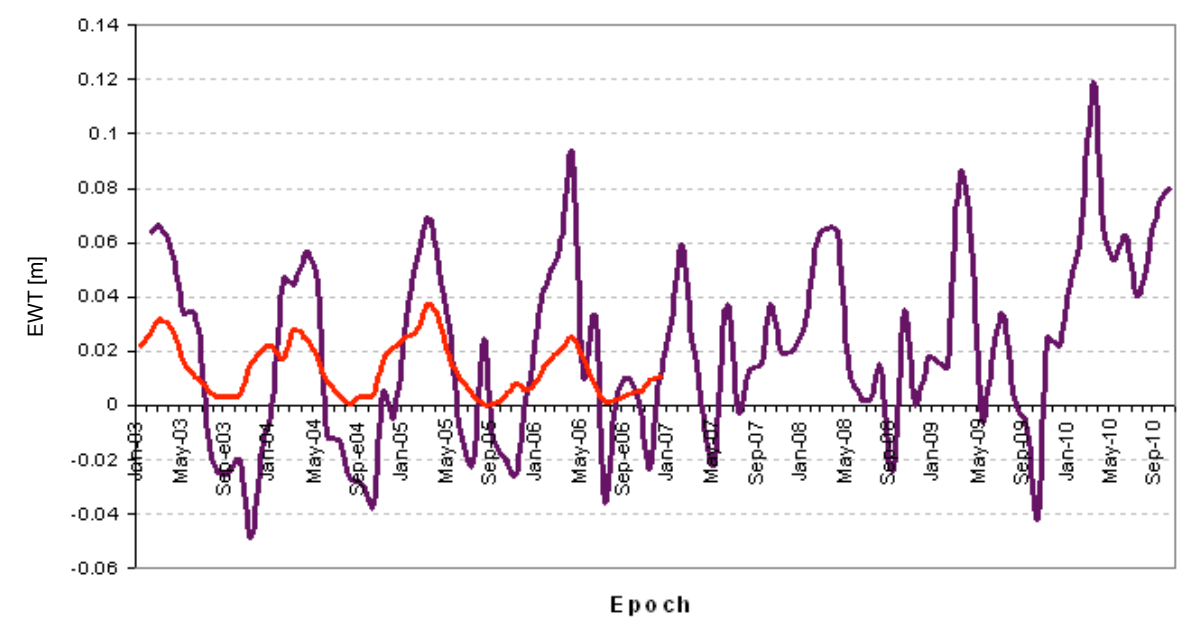

Figure 2. Equivalent Water Thickness from GRACE satellites (in violet) and from NOAA model (in red) 
Terrestrial hydrosphere NOAA data have been shifted in such a manner that it has a similar reference surface as presented in Figure 1 GRACE model. In the second step, the scale in the vertical direction was changed to fit both models (Fig. 3). Scaling NOAA model is made using the equation (4) to modify the signal.

$$
\sum_{i}^{N}\left(S_{i}^{P}-A S_{i}^{F}\right)^{2}
$$

Where: $S_{i}^{P}$ and $S_{i}^{F}$ are EWT values of each model, $\mathrm{N}$ is a number of months, A - scaling/modification coefficient. A result is presented in the Figure 3.

A modification coefficient of model elements (calculated value of 0.016 ) was determined by comparing the original GRACE model and the NOAA model.

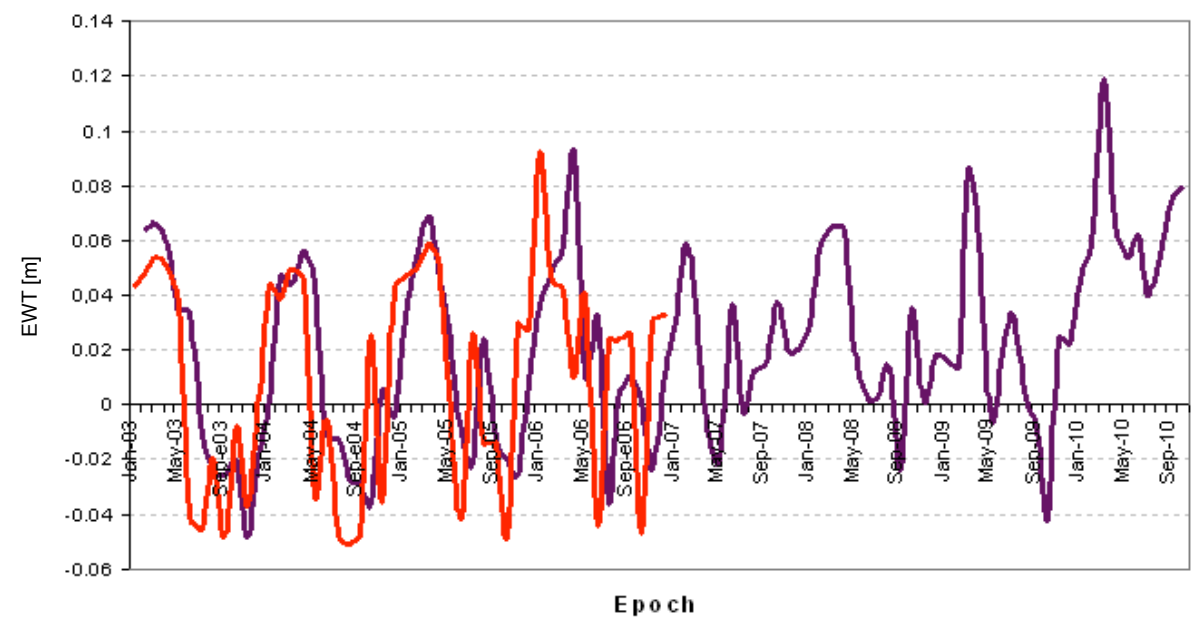

Figure 3. Equivalent Water Thickness from GRACE satellites (in violet) and from modified NOAA model (in red)

WaterGAP Global Hydrological Model (WGHM) is a meteorological model that contains data in the form of half-degree grid. WGHM data are published every month, made up the variables on precipitation, number of rainy days in the month, temperature and cloud cover. The most important parameter is precipitation, because this just have a significant impact on the water cycle. Currently, data are available for the period: $1951.1 \div 2005.12$ (Fiedler and Doll 2007). WGHM is a model defining the richness and use of water resources, there is a combination of water changes due to natural processes and human activities (Alcamo et al. 2003). The model consists of four components: surface water, snow, groundwater, soil (Gunter et al. 2007). Comparison between GRACE model and WGHM model is presented in Figure 4.

Like the NOAA model, WGHM model was modified with EWT modification factor (a value of 0.0065 was counted) presented as equation (2), and used to calibrate the primary sequence (Fig. 4). Results are presented in Figure 5. 


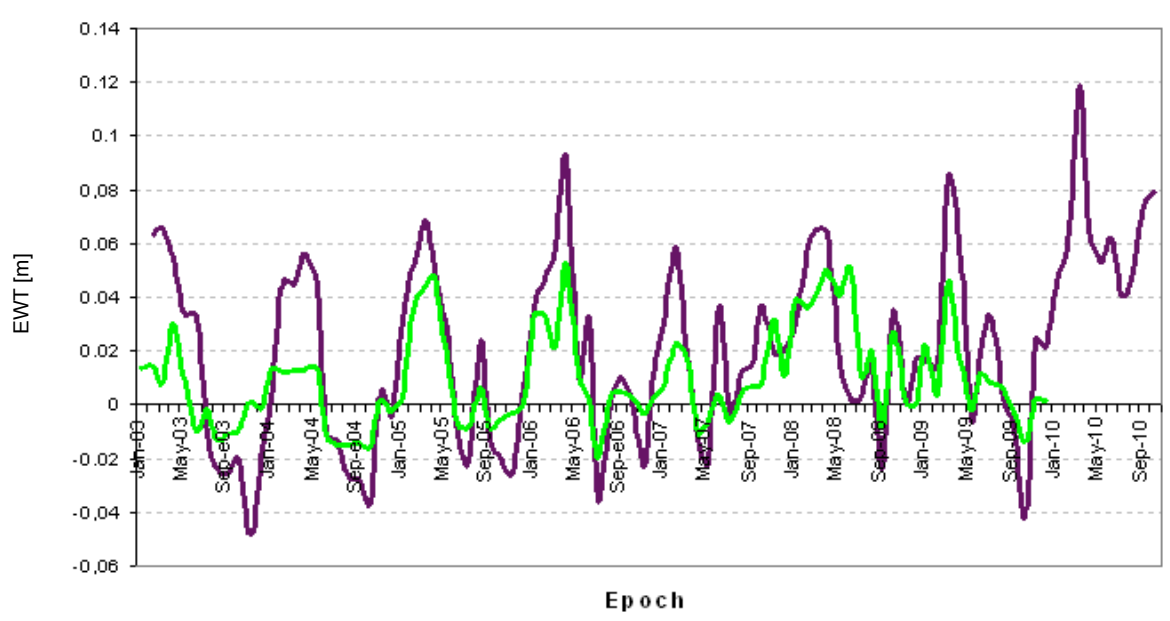

Figure 4. Equivalent Water Thickness from GRACE satellites (in violet) and from WHGM model (in green)

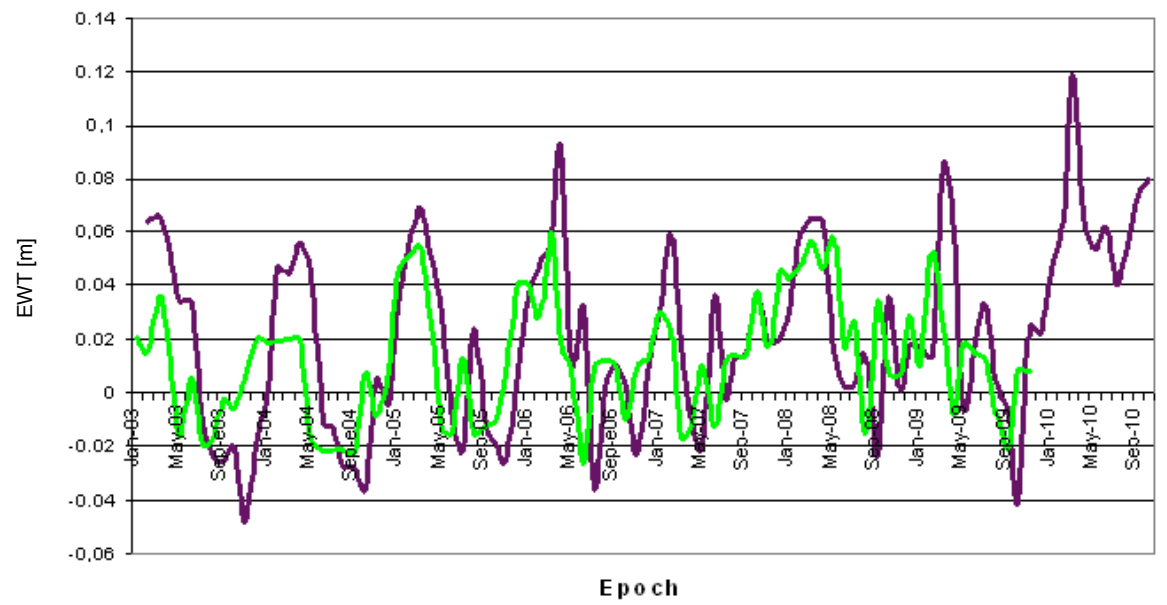

Figure 5. Equivalent Water Thickness from GRACE satellites (in violet) and from modified WHGM model (in green)

As can be seen from Figures $1 \div 5$ EWT derived from GRACE observations and land hydrosphere/meteorological models are characterized by a high degree of similarity, although the graphs obtained from the land hydrosphere/meteorological models contain more short-term changes). The correlation coefficient calculated for the data set GRACE and terrestrial hydrosphere dataset NOAA was 0.61 , while for the GRACE data set and the set of the meteorological model data WGHM 0.80. In the case study of the obtaining correlation coefficient between the models NOAA and GRACE is found one-month shift between models. Based on the analyzes it can 
be very likely to say that GRACE data is very useful for monitoring flood risk and climate change. The Figures 3 and 5 clearly shows high accuracy of model constructed using ANS filter (using the filtration results from research work carried out on the best filter to test for changes in regional EWT).

\section{GROUND WATER ABSORPTION IN THE ANALYZED REGION}

Instead of the intensity and the spatial and temporal distribution of rainfall, also natural retention has a significant role in flood risk Retention of rain water near the rain fall occurrence, has a great influence on making lower the climax flows in a river, as it can reduce surface runoff. Volume of surface runoff is reduced by evaporation of water into the atmosphere directly from the ground, with the donation of land cover and plants transpiration. Natural retention is dependent on terrain and cover, geological conditions, and the degree of development of the basin. In the case of the surface area covered with vegetation retention is significant. If there is such situation, water absorption takes place with a delay. The area with vegetation about $0-20 \%$ rainwater flows (Geiger and Dreiseitl 1999), and the retention of the sealed surface is much smaller. On the surface this is a quick and significant outflow.

The type of soil, the coverage, the degree of hydration of terrain, the type of rain and orography depends on the amount of water infiltrating into the soil. Dependence on soil type and coverage is presented in a Table 1.

Table 1. Dependance on ground type, coverage and percentage of water infiltered into ground (Mielcarzewicz 1970)

\begin{tabular}{|c|l|c|}
\hline \multirow{2}{*}{ Type of ground } & Percentage of water infiltered into ground \\
\hline \multirow{3}{*}{ Sand } & without coverage & 65 \\
\cline { 2 - 3 } & with coverage & 14 \\
\hline \multirow{3}{*}{ Clay } & without coverage & 33 \\
\cline { 2 - 3 } & with coverage & 13 \\
\hline \multirow{3}{*}{ Peat } & without coverage & 44 \\
\cline { 2 - 3 } & with coverage & 9 \\
\hline
\end{tabular}

The terrain that was analyzed is characterized by large influence of human being. This extremely enlarge flood risk, that means: deforestation, drainage systems building, covering all terrain with asphalt and concrete. In addition, the south of Poland have an average 900 millimeter level of rain. The southern part of Poland can be also described as region with fertile soil on agricultural land (warp soil in upper river flow and great coverage with anthropogenic soils in fields), which causes poor retention features. The last aspect, that should be examined for the purpose of the paper is forest cover. All these aspects show great need of flood monitoring. 


\section{CONCLUSIONS}

Based on analyses performed in the study, we conclude that the GRACE data can be used to test the feasibility of predicting flood events in Poland.There was a significant time-series data covering between GRACE observation and land hydrosphere NOAA and WGHM models. Interpretation of the data leads to the conclusion that the observation of an Equivalent Water Thickness in March will prepare for the dangers of flooding southern Poland. However, it is necessary to extend the hypothesis of issues related to meteorology, geology and soil science. It was made briefly, but for further analysis more extender knowledge is needed. On a basis of geological, forestry cover and soil type maps it was concluded that retention of the southern Poland is not on a high level, what makes flood risk monitor more important and essential.

Demonstrated the possibility of using data from the GRACE satellite observations to perform showed possibility of fulfilling the tasks arising from the Directive 2007/60/ EC of the European Parliament and of the Council on the assessment and management of flood.

\section{ACKNOWLEDGEMENTS}

A work is supported by the National Science Centre, contract number NN 526 157040 and 2145/B/T02/2011/40 of May 16, 2011.

\section{REFERENCES}

Alcamo J., Doll P., Henrichs T., Kaspar F., Lehner B., Rosch T., Siebert S., Vassolo S., 2003, The global water model WaterGAP 2: Water use model, Hydrological Science, 48, 3, DOI:10.1623/hysj.48.3.317.45290.

Beerer J.G., Massmann F.H., 2007, Status GRACE Mission Operations, GRACE Science Team Meeting, Potsdam.

Chambers D.P., 2006, Converting Release-04 Gravity Coefficient into Maps of Equivalent Water Thickness, Geophysical Research Letters.

Drożyner A., 2005, Badanie Ziemi metodami kosmicznymi na początku XXI w. (Earth research with cosmic methods at the beginning of XXI century), Rozdział w Zeszytach Naukowych VII Wyższej Szkoły Gospodarki Krajowej w Kutnie, wydanie specjalne (A chapter in Zeszyty Naukowe VII Wyższej Szkoły Gospodarki Krajowej w Kutnie, special edition), 56-62.

Dynowska I., 1993, Zmiany stosunków wodnych w Polsce $w$ wyniku procesów naturalnych $i$ antropogenicznych (Water balance changes in Poland as a result of natural and anthropogenic processes), Kraków, Wydawnictwo Uniwersytetu Jagiellońskiego.

Directive 2007/60/EC of the European Parliament and of the Council on the assessment and management of flood risk, from 23 rd October 2007. 
Fiedler K., Doll P., 2007, Global modeling of continental water storage changes - sensitivity to different climate data sets, Advances in Geosciences, 11 (In review).

Geiger W., Dreiseitl H., 1999, Nowe sposoby odprowadzania wód deszczowych (New methods of a rainfall water discharge), Oficyna Wydawnicza Projprzem-EKO, Bydgoszcz.

Gunter A., Stuck J., Werth S., Doll P., Verzano K., Merz B., 2007, A global analysis of temporal and spatial variations in continental water storage, Resources Research (AGU), 43, W05416, DOI: 10.1029/2006WR005247.

Klees R., Liu X., Wittwer T., Gunter B.C., Revtova E.A., Tenzer R., Ditmar P., Winsemius H.C., Savenije H.H.G., 2008, A comparison of global and regional GRACE models for land hydrology, Survey Geophysycal, 29, DOI: 10.1007/s10712-008-9049-8.

Klęski żywiołowe, Prognoza, zapobieganie (Natural disasters, forecast preventing), 1993, IMiGW, Warszawa, $4^{\text {th }}$ issue of a Project: Climate - an investment in your future (Projekt klimat - inwestujemy w Waszą przyszłość), IMiGW constraction team under direction of Lorence $\mathrm{H}$.

Liu X., 2008, Global Gravity Field Recovery from satellite-to-satellite tracking data with the acceleration approach, $\mathrm{PhD}$ thesis published in Publications on Geodesy, 68.

Mielcarzewicz E.W., 1970, Melioracje miejskie i przemystowe (Urban and industrial drainage), PWN, Warszawa.

Mioduszewski W., Pasternak A., 1995, Ochrona przeciwpowodziowa na obszarze Żuław (Flood protection of Żuławy area), Inżynieria Morska i Geotechnika, 6.

Nastula J., Paśnicka M., Kołaczek B., 2011, Comparison of the geophysical excitations of polar motion from the period: 1980.0-2009.0, Versita, Acta Geophysica, 59, 3.

Powódź w dorzeczu górnej Wisty w lipcu 1997 roku (Flood in the upper Vistula basin in July 1997), 1998, Materiały Konferencji Naukowej, Kraków, Wydawnictwo PAN (Conference proceedings, Krakow, Wydawnictwo PAN) under review of Starkel L., Grela J.

Tapley B., Bettadpur S., Ries J., Thompson P., Watkins M., 2004, GRACE measurements of mass variability in the Earth system, Science Magazine AAAS 23, Vol 5, DOI: 10.1126/ science.1099192.

Tapley B.D., Reiger Ch., 2008, The GRACE Mission, Status and Results, 2nd International GOCE User Workshop, Italy.

Veselinova-Renglova E., 2007, A Dynamic Geoid Model for Canada, A thesis submitted to the faculty of graduate studies in partial fulfillment of the requirements for the degree of doctor of philosophy, UCGE Reports Number 20261.

Watkins M., Gruber T., Bettadpur S., 2000, Science Data System Development Plan GRACE, Revision C, dokument wydany i publikowany przez Information System and Data Center (http://isdc.gfZ-potsdam.de).

Zhang Z.Z., Chao B.F., Lu Y., Hsu H.T., 2009, An effective filtering for GRACE time-variable gravity: Fan filter, Geophysical Research Letters, 36.

http://geophy.uni.lu/ggfc-hydrology.html, 12 th september 2011.

www.noaa.goerv, 9 th $^{\text {th }}$ October 2011.

http://geophy.uni.lu/ggfc-hydrology.html, 12 th September 2011. 